\title{
Extreme flash floods in Barcelona County
}

\author{
A. Barrera, M. Barriendos, and M. C. Llasat \\ Meteorological Hazards Analysis Team (GAMA), Department of Astronomy \& Meteorology, Faculty of Physics, University \\ of Barcelona, Av. Diagonal 647, E-08028 Barcelona, Spain
}

Received: 24 October 2004 - Revised: 18 March 2005 - Accepted: 21 March 2005 - Published: 2 May 2005

\begin{abstract}
In this paper the catastrophic and extraordinary floods occurring in Barcelona County (Catalonia, NE Spain) are studied, in order to characterise the temporal evolution of extreme flash floods in that area and their main features. These events usually cause economical losses and major problems for undertaking daily activity in Barcelona city. This kind of floods is a very common feature in the Northeast of Spain and they are recorded every year in some point of Catalonia. This contribution also shows the frequency of those events, within the framework of all the floods that have occurred in Barcelona since the 14th century, but also describes the flooded area, urban evolution, impacts and the weather conditions for any of most severe events. The evolution of flood occurrence shows the existence of oscillations in the earlier and later modern age periods that can be attributed to climatic variability, evolution of the perception threshold and changes in vulnerability. A great increase of vulnerability can be assumed for the period 1850-1900. The analysis of the time evolution for the Barcelona rainfall series (1854-2000) shows that no trend exists, although, due to the changes in urban planning, flash-floods impact has changed over this time. The number of catastrophic flash floods has diminished, although the extraordinary ones have increased.
\end{abstract}

\section{Introduction}

Flash floods are a very common feature in the North-east of Spain. Every year, during the summer or at the beginning of autumn, this kind of floods affects the littoral mountains or the Pyrenees region. Sometimes they can also occur in spring (Llasat et al., 2003). Usually the maximum accumulated rainfall is less than $100 \mathrm{~mm}$, with instantaneous intensities above $3 \mathrm{~mm} / \mathrm{min}$. They are associated with convective events for which more than $30 \%$ of the accumulated rainfall has an intensity of above $35 \mathrm{~mm} / \mathrm{h}$. On some occasions, this per-

Correspondence to: A. Barrera

(tbarrera@am.ub.es) centage surpasses $80 \%$, although these are very brief events (Llasat, 2001). Sometimes, however, more than $250 \mathrm{~mm}$ can be recorded in $3 \mathrm{~h}$. Depending on orography, human settlements and other factors, flash floods can produce catastrophic impacts. This was the case of the events of 5 September 1389, 8 April 1794, 14 September 1862, 21 September 1995 or 31 July 2002. Research into historical climatology shows this constitutes natural behaviour in this region, despite natural climatic variability, although flood impacts have evolved over time.

The main objectives of this paper are: 1) identification and classification of historical floods, and characterisation of flash-floods among historical floods for Barcelona county, reviewing prior works concerning this topic (Barriendos and Martín-Vide, 1997 and 1998) and developing more accurate information, basically for the last 150 years, 2) identification of meteorological trends that could explain the historical evolution of flood occurrence, especially for the 1850-2000 period for which continuous rainfall data series exist, and 3) identification of the influence of urban development on the vulnerability to floods.

The paper deals with the evolution of flash floods in Barcelona county since the Roman Epoch (although flood data are only available since the 14th century) down to the present day, taking account of the changes that have occurred in the water courses and in urbanization. First of all, the geographic and historical evolutions are presented. Once the flash flood events and their attendant damage have been identified, the main climatological features are discussed. Floods that have occurred in other basins have been also considered. Finally, some flash-flood events are presented in order to show the different patterns of human response to those hazards: a) human settlement that take account of natural conditions; b) structural protections (walled perimeters with hydraulic functions); c) living with the natural conditions without taking account of the phenomena (urban growth with no planning or precautions); d) non-obstructive structural works (drainage networks and underground water reservoirs to regulate overflowing). 


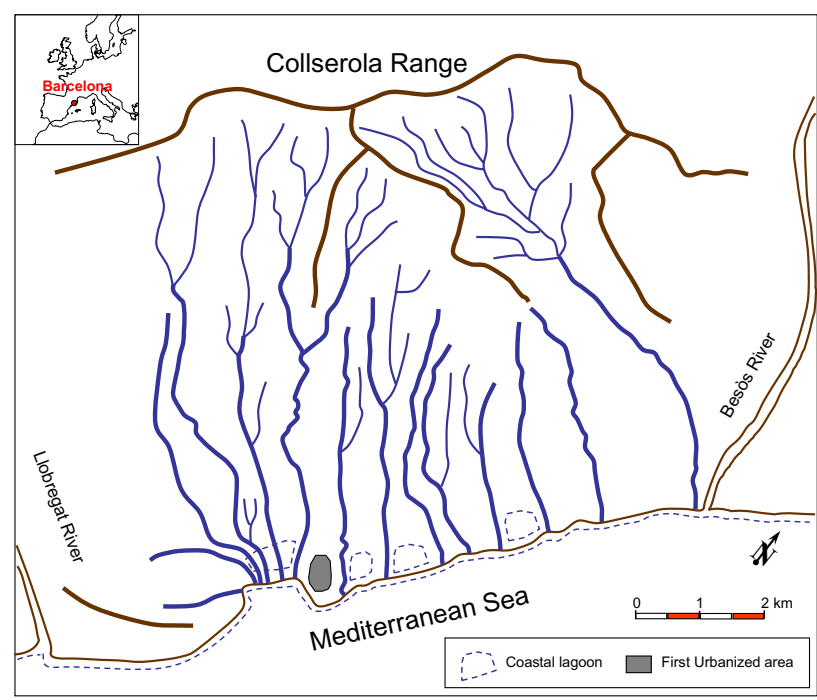

Fig. 1. Water courses in Barcelona county under natural conditions. Data obtained from Casassas i Simó (1984), Granados (1984), Olivé i Guilera (1993), Riba i Arderiu (1993), Sanz-Parera (1988), Travesset-Queraltó (1994) and Vila (1974). Urbanized area corresponds to period $200 \mathrm{BC}-\mathrm{AD} 1250$.

\section{Geography of Barcelona County and its historical evolution}

The city of Barcelona (NE Spain) is situated in a Quaternary plain between two rivers, the Llobregat River to the SW and the Besòs River to the NE. The plain is delimited by the coast and the Collserola range (Palaeozoic formation), with maximum altitudes around $500 \mathrm{~m}$, and with an area of $120 \mathrm{~km}^{2}$. Twelve short water courses (ouadis), with a strong slope and non-permanent flow, traverse this plain in parallel (Fig. 1). When heavy rains or a long rainy period arise over or near the city, their overflowing can produce significant damage, and floods, landslides and temporary lagoons can be recorded. Nowadays, most of these water courses are channelled and they belong to Barcelona's drainage system, with most of them interconnected. This network has been improved in recent years with the construction of underground water reservoirs into the city. As a consequence, heavy rainfall effects over the city are not the same as in the past.

Barcelona city has had a complex but interesting historical evolution. The relationship between human occupation and environmental conditions generates most definitive urban configurations and location of infrastructures. There nevertheless exists no clear perception of this evolution, flood risk and different mitigating strategies as key factors considered by authorities in managing urban planning. An overview can offer interesting experiences and coexistence patterns. The evolution of Barcelona city, from a consideration of flood risk criteria, can be defined in seven different stages:

a) BC 200-AD 1250: Throughout the presence of the Roman Empire, practically natural conditions remained. Taber hill (16 m a.s.l.) was used for human occupation, thereby avoiding flood risk. Barcino was a small city surrounded by littoral lagoons fed by small temporary rivers (Fig. 1).

b) 1250-1350: The Early Middle Age experiences the first flood risk assumptions, occupying temporarily flooded areas and littoral lagoons. An opened walled perimeter was designed with military function, but also to manage the floods, diverting flows out of the urbanized quarters. Unfortunately, no systematic documentary sources are available for this period. Flood events were not yet recorded (Fig. 2a).

c) 1350-1550: The Late Middle Age brought urban growth, generating a third walled perimeter. This renewed powerful infrastructure drove water flows into trenches. Flood events were recorded, but most of the damage occurred in this first infrastructure or in at the outlet from trenches, close to littoral lagoons. This planning strategy allowed, albeit with limited technology, an evident reduction of impacts caused by flooding in the urbanized sector of the city (Fig. 2b).

d) 1550-1750: The Early Modern Age brought a negative factor for flood situation managing. The presence of Turkish pirates in the Mediterranean Sea rendered necessary the construction of a "Sea Wall", enclosing the city completely, because dynamic defence with galleys was unsuccessful. Large rainfall events producing floods were managed by combination of walls and trenches with relatively good results. Problems arose with flash floods, when torrential rainfall was recorded into the city itself: a new dam effect was produced by the "Sea Wall" because of drainage limitation (Fig. 2c).

e) 1750-1850: Late Modern Age. The only important changes affected the eastern area, with the construction of a new fortress. The last remaining coastal lagoons disappeared. Fluvial processes did not change in relation to the previous pattern (Fig. 2d).

f) 1850-1900: Early Contemporary Age. During this short period, the traditional protection of walled perimeter was removed, but was replaced by other operative infrastructure to manage flood events. Barcelona, with one of the highest human density levels of its history, experienced a return to natural conditions. Most of nonpermanent rivers recover their ancient beds into or close to the city (Fig. 2e).

g) 1900-21st century: A new period of flood risk management started with the drainage network programme of 1890. Following different steps, during this century a new fluvial system was organized at underground levels, including pumping stations, water reservoirs and a warning system, to manage the flood events affecting the more vulnerable human activities (Fig. 2f). 


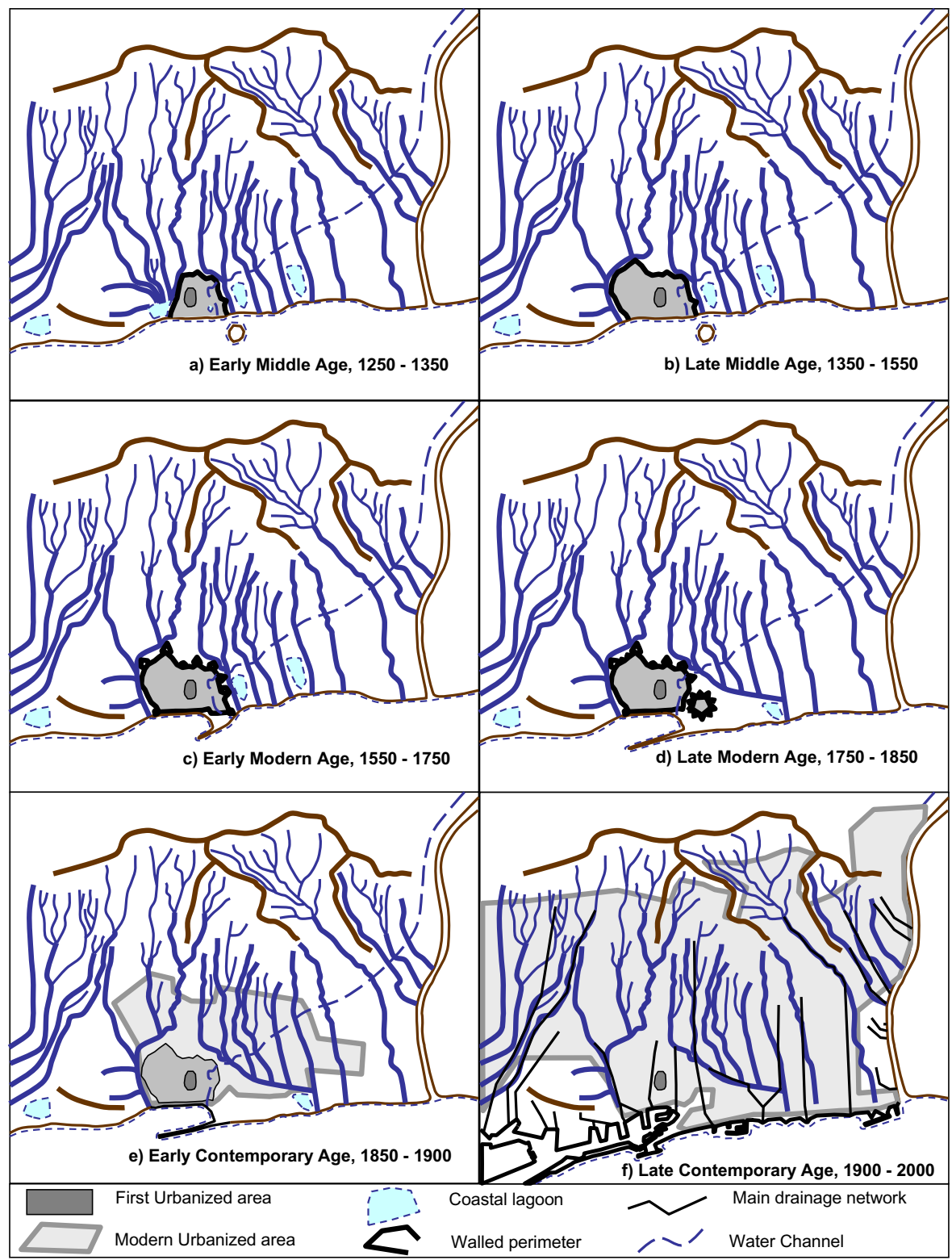

Fig. 2. Barcelona city urban evolution from the 14th century to the present: (a) AD 1250-1350; (b) AD 1350-1550; (c) AD 1550-1750; (d) AD 1750-1850; (e) AD 1850-1900; (f) AD 1900-2000.

\section{History of floods in the Barcelona county: occurrence and impacts}

In order to organise historical information in conjunction with modern data a common criterion to classify flood events has been used. This criterion distinguishes between "ordinary" (flood without overflow and without material damage), "extraordinary" (overflow with damage), and "catastrophic" (overflow with destruction). More information about this methodology and other criteria to classify historical floods can be found in Barriendos and Llasat (2003a), Barriendos et al. (2003b, 2003c), Lang et al. (1998). A flood can be considered as a flash flood taking account rainfall duration (some hours) and the response speed of the basin. For the most recent cases, the rainfall intensity has been also taken into account. A first proposal of flash floods for small basins like Barcelona county might consist in sudden floods produced by an intense rainfall event which lasts less than $6 \mathrm{~h}$ and accumulates more than $50 \mathrm{~mm}$ within this period.

In Barcelona, reconstruction of historical flood chronologies for the past 650 years has allowed the identification of 40 catastrophic floods and 44 extraordinary floods since 1351 , $64 \%$ of which could be considered flash floods. Seasonal distribution shows that autumn, followed by summer, is the season with the highest number of floods, and September (29 cases), followed by October (20 cases), as the month with the highest record. September also shows the greatest number of flash floods, with $83 \%$ of the monthly total. 


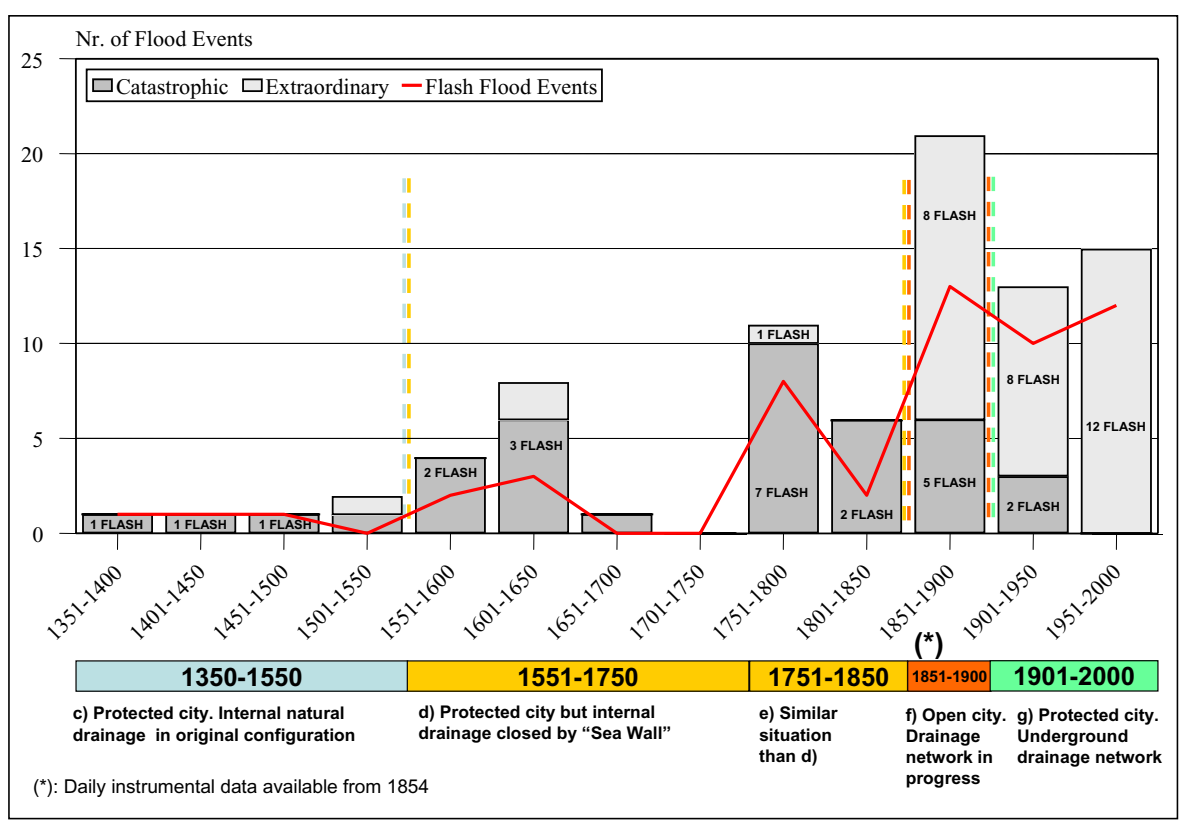

Fig. 3. 50-year period flood distribution in Barcelona county from AD 1351 to 2000.

Figure 3 shows the number of floods recorded from 1351 until 2000, for 50-year periods. The number of flash floods for each period is also included. Catastrophic events affect the city in spite of protection efforts. The record of their impacts shows the chronology of natural phenomena producing severe floods. This figure provides information on the evolution of flood occurrence in relation to meteorology and on the evolution of vulnerability. Climatic oscillations can be observed in the early and late modern age periods: some periods that last 40 years show an increasing frequency of events (i.e. 1580-1620, 1760-1800), while other longer periods show a lower occurrence of floods (1660-1760). This kind of variability is also observed for the entire Catalonia region (Barriendos and Llasat, 2003a). Besides this, the evolution of flood occurrence shows an increase of extraordinary events in conjunction with an increase of flash flood events over the last 150 years.

After five centuries of relatively low vulnerability, in which only extreme events affected the city but destroyed external walls, Barcelona experienced a short period of 50 years (1851-1900) with an abrupt increase of vulnerability (Fig. 3). Really, it was a human collective decision, preferring rapid and complete destruction of the walled perimeter before the planning and construction of pertinent networks for different services including drainage had been addressed. The increase of extraordinary events, practically unknown during Middle and Modern Ages, was simply the result of the abrupt change of environmental conditions: a 19th century industrial city was converted over the course of 50 years back to natural conditions like those of 2000 years earlier. A comment should be added on the evolution of the perception threshold by society. It might be observed that the few events documented in the Middle Ages period could be attributed to a higher perception threshold (probably only the main catastrophic events are documented in archives).

From a human perspective, people did not retain any memory of such frequent flood events. Then, the reaction was positive but planning and implementation of infrastructures to diminish vulnerability took several decades. Meanwhile, Barcelona is an excellent field of research into how flash floods affected an urbanized area: local newspapers describe all hydrologic aspects and damages.

On the other hand, Barcelona has the oldest daily precipitation series on the Spanish Mediterranean coast (1854 2000). Then, a climatic approach from instrumental data since the 19th century can also be made. Besides the rainfall features of each event, the main climatic aspects of the daily precipitation in Barcelona and its possible relationship with an increase or decrease of flood number are analysed. The total number of days with appreciable precipitation ( $\geq 0.1 \mathrm{~mm})$ is 10610 (20\% of days). These days are distributed as follows: $81 \%$ days with $\geq 1 \mathrm{~mm} ; 5.3 \%$ days with $\geq 30 \mathrm{~mm} ; 1.6 \%$ days with $\geq 50 \mathrm{~mm}$ and $0.1 \%$ days with $\geq 100 \mathrm{~mm}$. There is no day with $\geq 200 \mathrm{~mm}$. The threshold of $50 \mathrm{~mm} /$ day was considered in order to look systematically for flood events in the city for the period 1854-2000. This value coincides with the mean monthly rainfall, and has an average frequency of 1 case per year. The evolution of monthly maximum daily precipitation shows no important trend; therefore, extreme precipitation has not been increasing.

\section{Comparative study of impacts}

In this paragraph, an example of flash flood for each period has been considered. Documentary testimonies for each 
flood event show different meteorological and impact aspects.

4.1 The Late Middle Age: The catastrophic flash flood of 5 September 1389

Contemporaneous testimonies show that walled perimeter had a function of city protection and management of river floods, diverting the flow to the sea around the perimeter. But the energy of the flash floods proved excessive for buildings close to the wall in the sector where rivers beds were intercepted by walls (especially St. Peter Quarter). Torrential rainfall for only $3 \mathrm{~h}$ was enough to bring down buildings. But the worst impact in a pre-industrial society was outside the city: water channels feeding water mills would remain out of service for two weeks. The city could not produce flour, and shortages and famine appeared temporarily.

\subsection{The Early Modern Age: The catastrophic flash flood of} 28 October 1591

This event is a typical example of torrential rainfall affecting of the Barcelona hinterland. Rivers overflowed with high energy against the walled perimeter. Urbanized sectors did not record damage, but various installations of the walled perimeter were destroyed (two bastions). The authorities deemed this damage acceptable, for the flooding did not produce casualties or other damage to productive activities.

\subsection{The Late Modern Age: The catastrophic flash flood of} 8 April 1794

This event only shows peculiarities close to the new fortress. The main water channel of the city contributed to flood events by bringing into this sector the overflow from the River Besòs. Without slope towards the sea, water reaching this sector produced floods in a dense urban area.

4.4 The Early Contemporary Age: The catastrophic flash flood of 14 September 1862

This is an example of extreme events with no protection. Fortunately the water did not have sufficient energy to destroy infrastructures and buildings, but in low parts of the city the flood had a magnitude unknown in previous centuries. Contemporary descriptions depict the city like a sea with only Taber hill free from flooding.

4.5 The Late Contemporary Age: The extraordinary flash flood of 21 September 1995 and ordinary flash flood of 31 July 2002

These are two examples of the efficiency of drainage infrastructures to reduce and mitigate the flood impacts of those events with high intensities and amounts of precipitation in the city. The September case turned a lot of streets into rivers, and the low part of the city, where the littoral lagoons existed in the past, were flooded due to high rainfall of $145 \mathrm{~mm}$ in less than $45 \mathrm{~min}$. This is a typical case of a flash flood produced by a sudden thunderstorm that the meteorological models did not forecast. This event spurred the construction of underground water reservoirs to provide better drainage. The July case only produced localised problems in the city despite more than $100 \mathrm{~mm}$ being recorded in less than $3 \mathrm{~h}$. This flash flood was produced by a thunderstorm that developed into a convective system that affected the Central coast of Catalonia. The first one could have produced catastrophic damages without a good drainage system and the second one, extraordinary effects in Barcelona city were it not for the water reservoirs.

\section{Conclusions}

The evolution of flood occurrence in Barcelona county, from 14th century until the present day, shows the existence of climatic oscillations in the early and late modern age periods, like 1580-1620, 1760-1800 and 1660-1760, and some trends that could be mainly related with climatic variability. The absence of trend in rainfall series from 1854 cannot explain the increased number of events over the last 150 years. Such a trend observed in the number of floods documented can be mainly attributed to evolution of the perception threshold and changes in the vulnerability from the middle of the 19th century. A great increase of the vulnerability can be assumed from 1850, and this vulnerability progressively decreases through to 2000 , considering that there was no significant trend in the rainfall series from 1854 to 2000.

The previous study has allowed three objectives to be attained. The first was to advance towards a general definition of flash floods in the Western Mediterranean area, for which no such definition exists. A first proposal could be sudden floods produced by an intense rainfall event which lasts for less than $6 \mathrm{~h}$ and accumulates more than $50 \mathrm{~mm}$ in this period; however, further studies are needed for other places along the Mediterranean coast. Secondly, the analysis of the time evolution for rainfall shows that no trend exists. However, due to the changes in urban planning, flash flood impact has changed over time. As a consequence, the number of catastrophic flash floods has diminished, although the extraordinary ones have increased. This fact is related with the third objective, which is to note the mitigation of flood impacts if a good drainage system is developed. The 1850-1900 period is an example of poor management and planning.

Acknowledgements. The authors thank the RAMSHES (REN200204584/CLI) Spanish project, the AMPHORE (Interreg IIIB MEDOCC 2003-03-4.3-I-079) European project and "Ramón y Cajal" Programme (Spanish Ministry of Education and Science) for enabling the drawing up of this paper. Our thanks also to the two anonymous referees of this paper for their interesting suggestions and comments.

Edited by: L. Ferraris

Reviewed by: P. Mengual and another referee 


\section{References}

Barriendos, M. and Martín-Vide, J.: Meteorological hazards in Barcelona as from historical records (from the 14th to the 19th century), Initial results concerning their plurisecular climatic pattern, in: Advances in Historical Climatology in Spain, edited by: Martín-Vide, J., Oikos-Tau, Barcelona, 133-156, 1997.

Barriendos, M. and Martín-Vide, J.: Secular climatic cscillations as indicated by catastrophic floods in the Spanish Mediterranean coastal area (14th-19th Centuries), Climatic Change, 38, 473491, 1998.

Barriendos, M. and Llasat, M. C.: The case of the "Maldá" Anomaly in the Western Mediterranean basin (AD 1760-1800): An example of a strong climatic variability, Climatic Change, 61(1), 191-216, 2003a.

Barriendos, M., Llasat, M. C., Barrera, A., and Rigo, T.: The study of flood events from documentary sources. Methodological guidelines for historical sources identification and flood characterization in the Iberian peninsula, in: Palaeofloods, Historical Floods and Climatic Variability: Applications in Flood Risk Assessment, edited by: Thorndycraft, V. R., Benito, G., Barriendos, M., and Llasat, M. C., (Proceedings of the PHEFRA Workshop, Barcelona, Spain, 16-19th October, 2002), CSIC, Madrid, 8792, 2003b.

Barriendos, M., Coeur, D., Lang, M., Llasat, M. C., Naulet, R., Lemaitre, F., and Barrera, A.: Stationarity analysis of historical flood in France and Spain (14th-20th centuries), Nat. Haz. Earth Sys. Sci., 3, 583-592, 2003c,

SRef-ID: 1684-9981/nhess/2003-3-583.

Casassas i Simó, L.: El Barcelonès, La hidrologia del pla de Barcelona, Gran geografia comarcal de Catalunya, 8, 16-20, 1984.
Granados, O.: El Barcelonès. La història, Gran geografia comarcal de Catalunya, 8, 40-48, 1984.

Lang, M., Coeur, D., Lallement, C., and Naulet, R. : Valorisation de l'information historique pour la prédétermination du risque d'inondation: application au basin du Guiers, Ingénieries EAT, 16, 3-13, 1998.

Llasat, M. C.: An objective classification of rainfall events on the basis of their convective features. Application to rainfall intensity in the North-East of Spain, International Journal of Climatology, 21, 385-1400, 2001.

Llasat, M. C., Rigo T., and Barriendos, M.: The "Montserrat-2000" flash flood event: a comparison with the floods that have occurred in the northeastern Iberian Peninsula since the 14th century, International Journal of Climatology, 23, 453-469, 2003.

Olivé i Guilera, J.: Les rieres del pla de Barcelona a mitjan segle XIX, Proceedings del III Congrés d'història de Barcelona, 2, 399-408, 1993.

Riba i Arderiu, O.: Assaig sobre la geomorfologia medieval de la ciutat vella de Barcelona, Proceedings del III Congrés d'història de Barcelona, 1, 171-176, 1993.

Sanz-Parera, M.: El pla de Barcelona: constitució i caracterstiques físiques, Els llibres de la Frontera, Sant Cugat del Vallès, Col. "Coneguem Catalunya", n. 25, 1988.

Travesset-Queraltó, M.: La xarxa hidrogrfica del Pla de Barcelona entre la riera de Magòria i la riera d'Horta, Finestrelles, 6, 57-70, 1994.

Vila, P.: El Barcelonès i Barcelona ciutat, Geografia de Catalunya, AEDOS, 3, 497-608, 1974. 